\title{
Professional Identities of Vocational High School Students and Extracurricular Activities
}

\author{
Bilge Aslan Altan ${ }^{1}$, Havva Ozge Altıntas ${ }^{2}$ \\ ${ }^{1}$ Faculty of Education, Mugla Sitkı Kocman University, Mugla, Turkey \\ ${ }^{2}$ Psychiatry Clinic, Madalyon Psychiatry Clinic, Ankara, Turkey \\ Correspondence: Bilge Aslan Altan, Faculty of Education, Mugla Sitk1 Kocman University, Mugla, Turkey.
}

Received: May 30, 2017

doi:10.11114/jets.v5i7.2446

Accepted: June 12, 2017 Online Published: June 13, 2017

URL: https://doi.org/10.11114/jets.v5i7.2446

\begin{abstract}
Vocational high schools are one of the controversial topics, and also the hardly touched fields in educational field. Students' profiles of vocational schools, their visions, and professional identity developments are not frequently reflected in the literature. Therefore, the main aim of the study is to research whether vocational high school students' professional identities are supported with extracurricular activities. Followingly, it was also researched whether vocational high school students' future professional identities complied with their selected school and/or specialized fields. The research was conducted on qualitative research approach through semi-structured question form and analyzed via descriptive and content analysis of qualitative research methods. Results revealed that vocational high school students did not take part in extracurricular activities regarding their professional identities since the schools did not organize these activities. The responses also emphasized that existing extracurricular activities organized outside of the school were insufficient and there was an immediate need for such activities. Additionally, most of the participants highlighted that they selected their schools/department as an obligation. Based on the results, it was revealed that vocational and technical high schools should not focus on extracurricular activities to improve students' basic and further skills. It is suggested that extracurricular activities should be cared more for students' academic and practice skills. Moreover, the students and their parents should understand and be introduced to the profession before they come to a future decision.
\end{abstract}

Keywords: vocational high schools, professional identity, extracurricular activities

\section{Introduction}

What do you want to be when you grow up? It is one of the most thought-provoking questions that people are constantly being exposed to since childhood. Some take it serious or make fun and respond differently. How does this answer, which changes continuously until the time of the real profession, become shaped? According to Erikson (1968), the answers to these questions are within the process of developing the individual's professional identity. This is the process in which the individual begins to prepare himself and his ideas, actions take place accordingly, and develops himself in this direction. The psychological and physiological age at which the individual begins to develop his professional identity according to the Turkish education system coincides with the high school years. That is to say, the most basic step of the professional identity development and the profession that the students will prefer are initiated with the decision of a high school.

High schools as dynamic institutions, where students start forming their professional identities, play an important role. First of all, it is important for schools to enrich the environments in which students are able to develop their business behaviors and hands-on training (Dewey, 2017) with physical equipment and facilities. Keeping schools open for 24 hours can also increase the frequency of students' practice and enrich the possibilities offered by the school. In this way, the school can be used as a workshop after course hours, and can become centers of interests for students. In addition to the effect of the school on professional identity, its impact on the individual's social life is also important. The integrating and socializing role of the school is also necessary for the sociological development of individuals. According to Ergun (1992), two of the most important tasks of the school are to develop social skills and to develop social consciousness to provide social integration. This process does not always have to be with in-school activities. It is also possible to support this process with extracurricular activities cooperating with academic curricula. 


\subsection{Vocational High Schools in Turkey}

Turkey maintains educational applications with centralized structure of Ministry of Education (Bolat, 2016). Under the control of MoNE, students have to attend K-12 as compulsory education. Starting from the beginning middle school, students have to take national exams and perform academic success before high school education. Based on their scores, they have the right to prefer a high school. Vocational High Schools are also of these high schools selected by students according to their academic success. However, these schools' scores as acceptance criteria are mainly below average. As a result, students with low academic success are directed to these schools only focusing on exam scores.

High schools are seen as an important step by students, teachers, administrators, and parents since it is the final level before a university or a profession. The emphasis on professional development and roles of high schools are also mentioned in the defined missions of the Turkish Education System. According to this definition, the main aims of a high school are: a. to provide students with common general culture and encourage them to get familiar with the society, seeking for solutions to the problems and contribute to the economic, social and cultural development of the nation; $b$. In the direction of the interests, wishes and abilities of the students, to prepare them for higher education, or for the profession, as well as for life or business areas. On the other hand, vocational high schools' missions are defined as: 1. Raising a loyal citizen, 2. Preparing youth in education to life, 3. Upskill individuals with upgrade level competencies, 4. Providing work force, 5. Advancing knowledge, ability, and competency in work force. As emphasized in the items, high schools in general pay attention to students' interests and desires, and require them to prepare for a profession or tertiary education with competencies.

\subsection{Vocational High Schools and Extracurricular Activities}

Vocational high schools as can be understood from their names have the primary goal of providing students with an occupation concentrating on craft skills mostly. The main aim of vocational and technical education is defined by Sezgin (2009) as providing the students with basic behaviors that will enable the individual to have an occupation which is recognized and accepted in business world. Glasser (1975) highlights that when talking about the characteristics of successful schools and countries, there will not be an effective contribution to solving the core problems of the country unless schools where children's abilities can be taken into consideration and their success can be shaped upon accordingly are offered. Therefore, it is important to note that to what extent the students' interests and abilities match with the vocational school, for what reason students prefer these schools, and to what extent extracurricular activities are integrated for the contribution to the development of the students' vocational qualifications.

Extracurricular activities are the activities that students participate directly or indirectly in and out of school, and they reinforce and enhance the academic curricula (Balyer \& Gunduz, 2012). It has been shown several times that the students gain some skills with the extracurricular activities and that their skills are more easily revealed by these activities (Logan \& Scarborough, 2008; Fredericks \& Eccles, 2006; Wylie, 2005; Lewis, 2004; Mahoney et al., 2001; Eccles \& Barber, 1999; Marsh, 1992). These activities, which can especially contribute to the professional development for the vocational high school students, are also important in the vocational high school programs to strengthen the connection between students and their professional identity in the fields where employment will take place. These organized social, cultural and professional activities can be varied as workshops, seminars, technical visits, profession-oriented activities and so on. Therefore, theory and practice can be run together. Holland and Andre (1987) highlighted that extracurricular activities highly and positively affected youth's participation, motivation, development, and fuction in many fields.

In the literature, individual development in terms of psychology, sociology, and physiology have been enhanced and reinforced with extracurricular activities in many studies. However, vocational training has not been meaningfully supported with extracurricular activities. This study was conducted hoping that extracurricular activities can be applied in professional development as well.

\subsection{Problem Statement}

Summarizing the literature briefly, it was found that vocational training and extracurricular activities could be complementary for many purposes. However, considering the Turkish education policies for high school selection, curriculum implementation in vocational high schools, and professional development of students, the research on the topics were seen as a need. Unfortunately, the issue of vocational high school students career-oriented development still seems controversial under these circumstances. The idea that vocational high school students have taken a more determined step in their career path is still not common and the studies aimed at examining it nationally also remain inadequate. In addition to the basic problems regarding vocational high schools and their applied curricula, there is also need for more information and development in extracurricular adaptations for students' skills and pre-service trainings. 
The aim of this study is to investigate whether vocational high school students support their professional identities, which they aim to have with the schools and / or departments they prefer, with extracurricular activities. It was also questioned whether they tracked the professional identity they wished to have for future.

Answers for the following questions in the light of the determined purpose were sought:

1. How did the vocational high school students decide their preferred departments / schools?

2. Are vocational high school students involved in extracurricular activities regarding their specialized area-to-be?

3. Do vocational high schools contribute to students' future professional identity with extracurricular activities?

4. If the vocational high school students wanted to make a different choice, what kind of department / school would they prefer?

With the study, it was tried to draw a profile of the vocational high school students' preferences, opinions, and actions, and to examine the place of the extracurricular activities in vocational high school programs. It is hoped that the results will support the field of vocational high schools' and extracurricular activities' developments.

\section{Method}

The research was carried out in the qualitative research method. Qualitative research provides relevant informational integrity obtained on a case (Patton, 2014). The holistic and related nature of qualitative studies' pragmatic philosophy were seen appropriate for this work. In this context, the students were questioned on the related topic and the responses they gave were examined. The results were divided into categories and the research questions were analyzed to be answered.

\subsection{Participants}

The participants studying in vocational high schools in a city of Turkey. The sample is based on the maximum diversity sample from the purposeful sample types, but since some of the existing vocational high schools are in the internship period, the lack of the desired target group has created a problem. For this reason, students in 4 out of 7 different vocational high schools formed the sample of the study. These schools are: Trade Vocational High School (13), Girls' Vocational High School (14), Religious Vocational High School (17), and Industrial Vocational High School (16). Participants in the selected schools were determined according to the criterion sampling method and 11th grade students were selected as participants. The selection criterion for the 11 th grade students is to select the specialized field and have started to take vocational courses. A total of 92 participants were reached, but 60 valid data were collected since voluntary participation in the study was requested. Other participants indicated that they did not want to participate in the study.

\subsection{Data Collection Instrument}

For the collection of data in the study, a form consisting of open-ended questions was developed by the researchers. In order to obtain the best results for the purpose of the study, these questions were collected in a question pool and evaluated by considering expert opinions. The question list was carefully and purposefully formed and the most appropriate examples of the questions were written. From these questions, the ones for the problem situation are determined. In order to control the internal validity, questions were piloted by 10 students from a vocational high school not included in the study. The final version of the form was presented for the participants' answers. Participants were asked to give the sincerest answers to the questions.

\subsection{Data Analysis}

The research has been examined in the inductive-holistic approach as the nature of the study. Content analysis is utilized for the procedure. In the procedure, the sequence of coding, distinguishing, categorizing and providing validity and reliability was followed. The analysis was examined separately by two researchers and then reunited. The percentage of agreement between researchers was checked for validity and reliability and found to be $86 \%$. Direct answers of the participants are shown in the findings section. Generated categories were evaluated and finalized in the light of the answers required for the research questions.

\section{Results}

Analyzes of collected data were evaluated under themes. According to these themes, some of the following findings have been reached. In addition to findings, the overall evaluation of the number of participants according to schools and the vocational schools with the most positive and constructive responses to their schools, professional identities and extra program activities was introduced in Table 1. In addition to the general distribution, the detailed findings of the are presented following the questions below. 
Table 1. Overall evaluation of participants' most positive responses

\begin{tabular}{ll}
\hline High Schools & $f$ \\
\hline Industrial Vocational High School & 9 \\
Religious Vocational High School & 4 \\
Trade Vocational High School & 10 \\
Girls' Vocational High School & 7
\end{tabular}

\subsection{Reasons for Preferences of Departments/Schools}

As a result of the analyzes made, the majority of the vocational high school students stated that they were obliged to choose the school / department they pursue. Regarding the responses of students, the obligation resulted from family influence or academic failure. Participants explained these reasons as; "I chose this school due to my parents. My family wanted it.", "I came here unwillingly. Elders told me it was the best for me.", "The only school which my academic score was adequate for was this school.", "My academic entrance score was low so that I ended up here.", "My dad recommended this department.", "I came here because of my parents' wish. I do not think that this department is right for me.", "My family wanted me to choose.", "My dad chose the school.", "Dad's profession will pass down, so I am here.", "I did not study hard, I ended up here because of my low success." However, the number of students who chose to study at a vocational high school with their own interests and wishes is also one of the observed results of the research. Students stated their willingness as, "I like to do hair so I chose this school.", "I want to be a lawyer so that I am in the department of justice.", "I chose this school to have a job sooner.", "I am interested in accounting. To be bank employer is my dream.", "To have a profession in a short time I came here.", "I love electricity business and my profession should be relevant to it." The themes formed by the answers given by the students are presented in Figure 1.

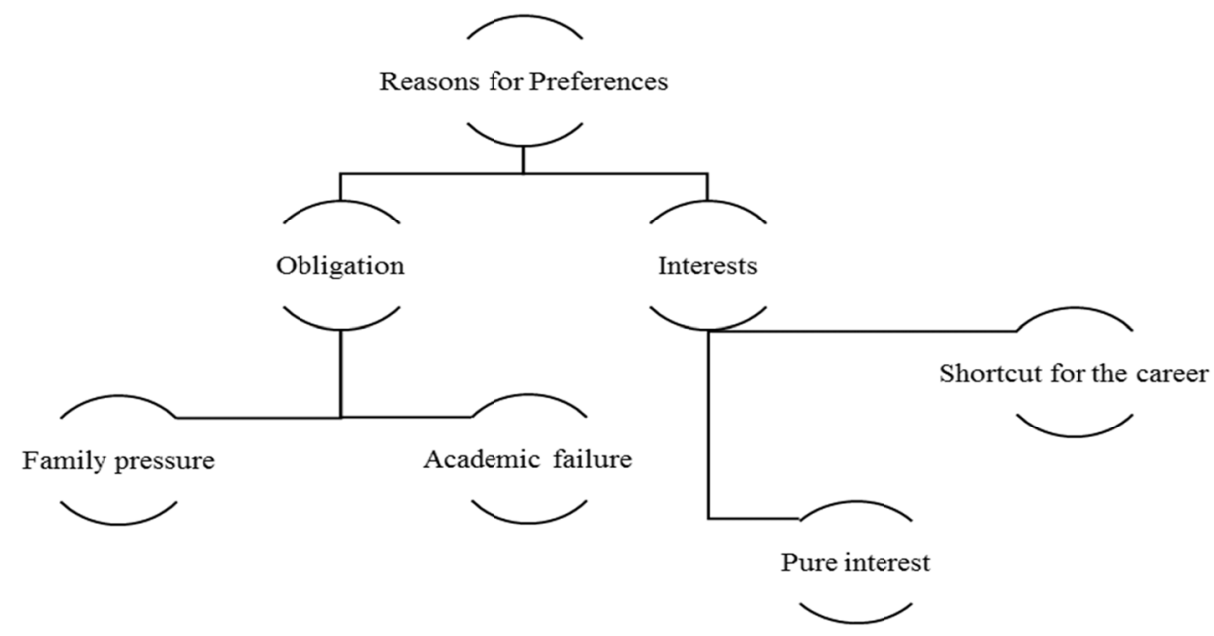

Figure 1. Themes for reasons of preferences

\subsection{Supporting Selected Departments with Extracurricular Activities}

Students were asked whether they participated in extra-curricular activities related to their professional identity. The vast majority of the participants indicated that they did not participate in such activities. They have expressed the reasons for not involving in such activities as a desire to avoid related activities because they often have a lack of time or due to the profession itself. Few students who have indicated that they are participating in extracurricular activities related to their professional identities have often stated that these activities are organized seldom and that they are disturbed by the inadequacy of the people and institutions to direct them to such activities, and the cost of the materials to be used is above their budget. These expressions are stated as, "No, not at all", "No, I don't participate in such activities since I do not want to have this job.", "No, because I do not have time", "I am involved in other types of activities not related to my profession. It is already enough being exposed to the activities which I really don't want to be in.", "Why did not you ask the teachers, I do not know how to do it. They are the decision makers for all of us.", "Everything out of this school is beyond my vision. Someone should organize these activities.", "Even participating in these activities in school needs money. We cannot afford the equipment for further." When asked about the activities they have been participating so far, they often stated that they had the compulsory and optional internship opportunities offered outside and there were a few workshops appropriate for their expected professions. 


\subsection{Contribution of School to the Professional Identity in Terms of Extracurricular Activities}

Participants often responded negatively to the question of how their vocational schools contribute to their professional identity in terms of subject, equipment, and practice. In addition to not contributing their professional identities, they have also stated that schools do not have the professional identity as a vocational school since the curriculum does not significantly differ from other types high schools. However, participants mostly complained about the schools only. They did not directly mention about the extracurricular activities organized in the schools. Participants stated their responses as, "There is no contribution. The school only teaches. We even buy the course materials and get low grades from these materials.", "There is not enough support for the profession that I want to have in this school. There is no enough time and equipment for me to practice. We always take exams and that's it.", "I think the school is insufficient to contribute to our future professions. For example, my specialized area is commerce, but I cannot learn the necessary tips and practice, the curriculum is so intense with common subjects.", "I cannot do anything other than sitting as like tourist in a lesson in this school where I came to practice a profession.", "We see the same subjects as in the other high schools. The time, subject and practice that are designed for vocational courses are not enough". A small number of respondents replied that the schools were contributing to their future profession in terms of curriculum. In addition, some participants stated that the schools they are studying in contribute to their own personal development as well. The main themes are stated in Figure 2. below.

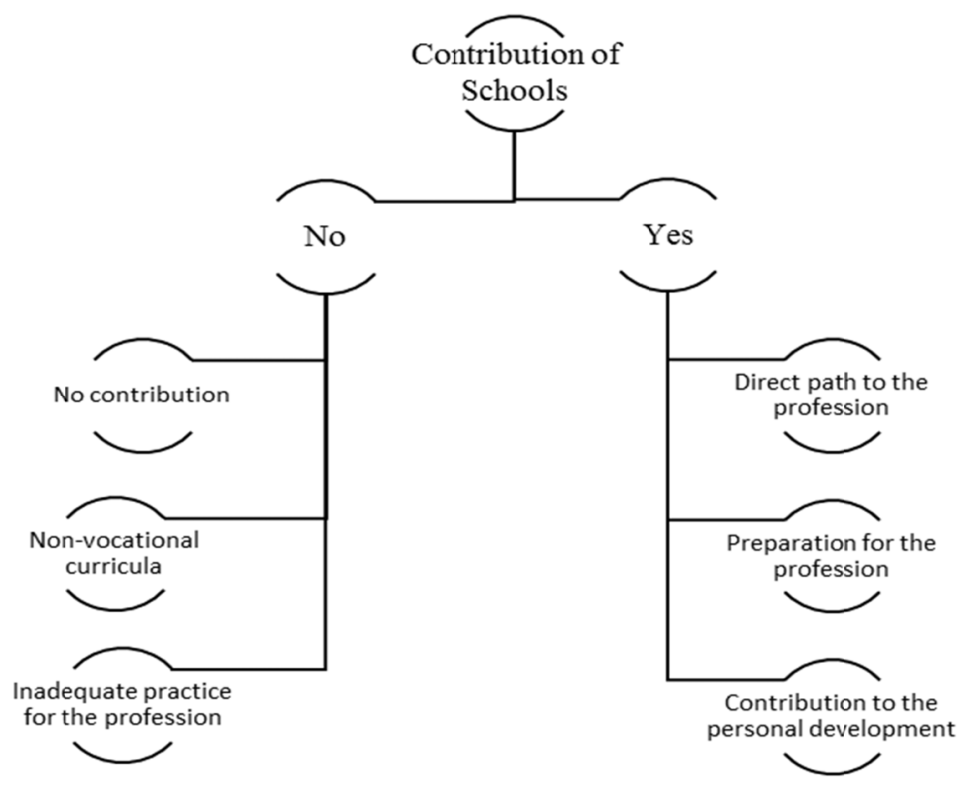

Figure 2. Main themes of contribution of schools to profession

\subsection{Chance to Choose a Different Profession and/or School}

As the research question, students were asked if they had been given a chance to make their own decision on their future profession, would they have changed their decisions. When students were asked whether they want to have a different field and/or professional identity, the answers were varied. The different selections were varied from different high schools to professions, as well as to even different vocational high schools. Some of the alternative professions and high schools given as responses are respectively: Police, Teacher, Tourism Employee, Cook, and Military High School, Health Vocational High School, Fine Arts High School and so on. There are only few students who have indicated that they want to continue the current profession and school.

\section{Conclusion and Discussion}

One of the most prominent results of the study has shown that vocational high school students are pursuing a professional identity mainly because of their family and academic failure impact. Most probably, they are directed to a vocational school due to their tendencies or abilities. When they make the first step for their professional identity, they mostly are deprived of activities outside the school to develop and support their both professional and personal identity. In general, the reason for this lack is reflected as not feeling of belonging to the professional identity they try to embrace. Besides, the inadequacy of organized extracurricular activities negatively affects their motivation and limits the practice frequency of their craft. Especially the idea that the schools do not contribute to the professional identity development is the common response given by the students of the vocational high schools. A significant number of people seeking a different professional identity at the first opportunity is also a significant result. The students who seem to have a particular 
professional identity track also highlighted that extracurricular activities in the vocational area are not sufficient, and once again revealed the gap between theory and practice.

Considering the results, it is once again understood that it is important for vocational high school students to be informed about schools and departments before making school or departmental choices. After middle schools, most of the students are directed to any high school regarding their academic success. Such an academic list of high schools label many students and vocational high schools become notorious. Since these students are under legal age to register to high school they determine, parents intervene with their own decisions. In order to prevent such labels and conflicts, vocational high schools should consider accepting students by evaluating their interests, tendencies, and abilities as fine arts vocational high schools do. However, before completing elementary schools, students should be oriented for vocational schools. This orientation should be organized not only for students but also for families. Thus, before deciding on the professions of their children, they may have knowledge of what professional identities they are planning for and can make better choices. Besides, it will be more meaningful to introduce and supervise the professional identity that the students will have before they choose the department.

Students seem to associate the academic failure with their existing professional identities. They believe that there are better professional alternatives, but these alternatives are beyond their reach and academic achievement. Particularly students who adopt fatalism seem to have convinced themselves that they have these professional identities because of their failures. At this point, the place of the extracurricular activities is important, although not yet noticed. Extracurricular activities in studies have been found to be highly effective in eliminating the academic failure, demotivation, feeling of loneliness and rejected of students and improving many professional and personal characteristics of students (McNeal, 1995). In addition, the extracurricular activities are aimed at increasing the level of educational attainment and self-esteem (Yarworth \& Gauthier, 1978; Otto \& Alwin, 1977; Otto, 1976; Rehberg \& Schafer, 1968; Hanks \& Eckland, 1976; Spady, 1970). Therefore, it is also suggested to increase the number of extracurricular activities and regular workshops for students to increase their faith in their assets and professional characters.

It is also not right to emphasize academic failure only for the students in vocational high schools. Academic failure is often confronted as a topic that today's students bewail globally. Success-based assessment and interpretation of such assessments mostly on paper-exams can create a paradox for students trying to have a craft work. It is not appropriate for these students, mostly with handcrafted professional identities, to be evaluated by paper-based tests. The choice of process-based assessment activities will strengthen both the professional skills of the students and increase their motivation for success (Hesapcioglu, 2011).

For many times in the state development plans, the importance of the vocational high schools has been emphasized and have been on the agenda in education councils. It is of great importance that the cooperation protocols should be initiated between private industry establishments and MoNE in order to contribute to increasing interest and demand for vocational and technical education. The widespread awareness of the importance of these schools for a strong industry and economic development is also closely linked to the dissemination of such projects. It is also important to regularly revise the content of the vocational high school curricula according to the vocational employment of the age, to secure and support effective employment of graduate students in private or public institutions / organizations, to supervise the approach of the teachers working in these schools and their pedagogical aspects for vocational high schools.

It is suggested that similar studies involving the expansion of the sample group and comparison of different local results are better to be conducted. A comparative study can also be conducted to investigate the different practicum, curriculum adaptation, and extracurricular activity organizations with other countries. Making needs analysis for the vocational high schools in line with educational policies and making psychological and sociological dimensions meet the needs of the vocational high school students will also contribute to field studies.

It should not be the case that rising generation all over the world accept a professional identity as their fates. They should be encouraged and taught to pursue a profession considering their interests and abilities. Therefore, effective employment and self-esteem can rise hand in hand. Feeling useful and successful, attending extracurricular activities, cooperating with government and industrial organizations can advance the productivity and education simultaneously.

\section{References}

Balyer, A., \& Gunduz, Y. (2012). Effects of structured extracurricular facilities on students' academic and social development. Social and Behavioral Sciences, 46, 4803-4807. https://doi.org/10.1016/j.sbspro.2012.06.338

Barber, B. L., Eccles, S. J., \& Stone, M. R. (2001). Whatever Happened to the jock, the brain and the princess?young adult pathways linked to adolescent activity involvement and social identity. Journal of Adolescent Research, 16(5), 429-455. https://doi.org/10.1177/0743558401165002

Bolat, Y. (2016). Turkiye'de Mesleki ve Teknik Egitimin Mevcut Durumu. Ankara: Pegem Akademi. 
Coleman, J. (1965). Adolescents and The Schools. New York: Basic Books.

Dewey, J. (2017). Okul ve Toplum. Ankara: Pegem Akademi.

Eccles, J. S., \& Barber, B. L. (1999). Student council, volunteering, basketball, or marching band: what kind of extracurricular involvement matters? Journal of Adolescent Research, 14, 10-43. https://doi.org/10.1177/0743558499141003

Ergun, M. (1992). Egitim ve Toplum. Ankara: Ocak Yayınlari.

Erikson, E. H. (1968). Identity, Youth and Crisis. New York: W. W. Norton Company.

Fredericks, A. J., \& Eccles, S. J. (2006). Is extracurricular participation associated with beneficial outcomes? concurrent and longitudinal relations, Development Psychology, 42(4), 698-713. https://doi.org/10.1037/0012-1649.42.4.698

Glasser, W. (1975). Schools Without Failure. New York.

Hanks, M., \& Eckland, B. (1976). Athletics and social participation in the educational attainment process. Sociology of Education, 49, 271-294. https://doi.org/10.2307/2112314

Hesapcioglu, M. (2011). Ogretim Ilke ve Yontemleri: Egitim Programlari ve Ogretim. Ankara: Nobel Yayin Dagitim.

Holland, A., \& Andre, T. (1987). Participation in extracurricular activities in secondary school: What is known, what needs to be known? Review of Educational Research, 57, 437-466. https://doi.org/10.3102/00346543057004437

Lewis, C. P. (2004). The Relation Between Extracurricular Activities With Social Competences In School Age Children. A Meta-Analysis: Texas A\&M University.

Logan, W., \& Scarborough, J. (2008). Connections through clubs: Collaboration and coordination of a school wide program. Professional School Counseling, 12(2), 157-161. https://doi.org/10.5330/PSC.n.2010-12.157

Mahoney, J. L., Schweder, A. E., \& Stattin, H. (2001). Structured after-school activities as moderator of depressed mood for adolescents with detached relations to their parents. Journal of Community Psychology, 30(1), 69-86. https://doi.org/10.1002/jcop.1051

Marsh, H. V. (1992). Extracurricular activities: beneficial extension of the traditional curriculum or subversion of academic goals. Journal of Educational Psychology, 84, 553-562. https://doi.org/10.1037/0022-0663.84.4.553

McNeal, R. B. (1995). Extracurricular activities and high school dropouts. Sociology of Education, 68, 62-81. https://doi.org/10.2307/2112764

Otto, L. B. (1976). Extracurricular activities and aspirations in the status attainment process. Rural Sociology,41, $217-$ 233.

Otto, L. B., \& Alwin, D. F. (1977). Athletics, aspirations, and attainments. Sociology of Education, 42, 102-113. https://doi.org/10.2307/2112373

Patton, M. O. (2014). Nitel Arastirma ve Degerlendirme Yontemleri. (Trns.). Ankara: Pegem Akademi (3.Edt.).

Rehberg, R., \& Schafer, W. (1968). Participation in interscholastic athletics and college expectations. American Journal of Sociology, 73, 732-740. https://doi.org/10.1086/224566

Sezgin, S. I. (2009). Mesleki ve Teknik Egitimde Program Gelistirme. Ankara: Nobel Yayin Dagitim.

Shulruf, B., Tumen, S., \& Tolley, H., (2008). Extracurricular activities in school, do they matter? Children andYouth Service Review, 30, 418-426.

Spady, W. G. (1970). Lament for the letterman: effects of peer status and extracurricular activities on goals and achievement. American Journal of Sociology, 75, 680-702. https://doi.org/10.1086/224896

Wylie, C. (2005). Leisure activities and adolescent engagement in school learning, New Zealand Council for Educational Research Paper presented at the NZARE, Dunedin, 1-12.

Yarworth, J., \& Gauthier, W. (1978). Relationship of student self-concept and selected personal variables to participation in school activities. Journal of Educational Psychology, 70, 335-344.

https://doi.org/10.1037/0022-0663.70.3.335

\section{Copyrights}

Copyright for this article is retained by the author(s), with first publication rights granted to the journal.

This is an open-access article distributed under the terms and conditions of the Creative Commons Attribution license which permits unrestricted use, distribution, and reproduction in any medium, provided the original work is properly cited. 